\title{
Chemical and structural composition of black pigmented supragingival biofilm of bovines with periodontitis ${ }^{1}$
}

\begin{abstract}
Saraiva J.R., Buso-Ramos M.M., Borsanelli A.C., Schweitzer C.M., Gaetti-Jardim Jr. E., Höfling J.F., Ramos T.N.M. \& Dutra I.S. 2019. Chemical and structural composition of black pigmented supragingival biofilm of bovines with periodontitis. Pesquisa Veterinária Brasileira 39(12): 933-941. Departamento de Apoio, Produção e Saúde Animal, Faculdade de Medicina Veterinária de Araçatuba, Universidade Estadual Paulista "Júlio de Mesquita Filho", Rua Clóvis Pestana 793, Cx. Postal 533, Jardim Dona Amélia, Araçatuba, SP 16050-680, Brazil. E-mail: iveraldo.dutra@unesp.br

Bovine periodontitis is a multifactorial disease primarily associated with a potentially pathogenic microbiota housed in the oral biofilm of animals. Biofilms are organized structures, in which the constituents coexist in symbiosis, already described as a predisposing factor to periodontitis in other species. The objective of the present study was to characterize the structure and chemical aspects of the bovine black pigmented supragingival biofilm using scanning electron microscopy (SEM) and energy dispersive spectroscopy (EDS), respectively, and determine its relationship with bovine periodontitis. Eleven premolar teeth from different animals were evaluated; five non-pigmented samples and six samples with black pigmented biofilms were initially submitted to SEM, and three areas of these samples were selected for EDS. The structure of the pigmented biofilm was more complex and irregular because of a higher content of mineral elements. The semi-quantitative EDS data indicated an association of iron $(\mathrm{p}<0.014)$ and magnesium $(\mathrm{p}<0.001)$ with the occurrence of periodontitis, whereas carbon, phosphorus, calcium, manganese, sodium, and potassium were not associated with the disease. Carbon $(p<0.039)$, manganese $(p<0.007)$, and iron $(p<0.015)$ were associated with pigmentation, whereas phosphorus, calcium, and magnesium were not associated with it. Spearman correlation test showed the relationships between calcium and phosphorus, and iron and silicon. The strong association of iron in the pigmented supragingival biofilm and with the occurrence of periodontitis suggests the presence of microorganisms that use this element in their metabolism and that are also associated with bovine periodontitis. This study suggests that the pigmented deposits in the crown of the teeth of cattle are an true
\end{abstract}

\footnotetext{
${ }^{1}$ Received on March 26, 2019.

Accepted for publication on June 6, 2019.

${ }^{2}$ Graduate Program in Veterinary Medicine, Faculdade de Ciências Agrárias e Veterinárias, Universidade Estadual Paulista "Júlio de Mesquita Filho" (Unesp), Via de Acesso Professor Paulo Donato Castellane s/n, Jaboticabal, SP 14884-900, Brazil.E-mail: julia_beca@hotmail.com

${ }^{3}$ Collaborating Researcher of the Graduate Program in Oral-Dental Biology, Departamento de Diagnóstico Oral, Faculdade de Odontologia de Piracicaba, Universidade Estadual de Campinas (Unicamp), Avenida Limeira 901, Areião, Piracicaba, SP 13414-903, Brazil. E-mail: marcellebuso@gmail.com

${ }^{4}$ Postdoctoral in Veterinary Medicine, Departamento de Produção e Saúde Animal, Faculdade de Medicina Veterinária de Araçatuba, Universidade Estadual Paulista "Júlio de Mesquita Filho" (Unesp), Campus de Araçatuba, Rua Clóvis Pestana 793, Jardim Dona Amélia, Araçatuba, SP 16050-680, Brazil. E-mail: carol_borsanelli@yahoo.com.br
}

\footnotetext{
${ }^{5}$ Departamento de Matemática, Faculdade de Engenharia de Ilha Solteira, Universidade Estadual Paulista “Júlio de Mesquita Filho" (Unesp), Alameda Rio de Janeiro 266, Ilha Solteira, SP 15385-000, Brazil.E-mail: chris@mat.feis.unesp.br

${ }^{6}$ Departamento de Patologia e Propedêutica Clínica, Faculdade de Odontologia de Araçatuba, Universidade Estadual Paulista "Júlio de Mesquita Filho" (Unesp), Campus Araçatuba, Rua José Bonifácio 1193, Araçatuba, SP 16015-050. E-mail: gaettijardim@gmail.com

${ }^{7}$ Departamento de Diagnóstico Oral, Faculdade de Odontologia de Piracicaba, Universidade Estadual de Campinas (Unicamp), Avenida Limeira 901, Areião, Piracicaba, SP 13414-903. E-mail: hofling2@unicamp.br

${ }^{8}$ Departamento de Produção e Saúde Animal, Faculdade de Medicina Veterinária, Universidade Estadual Paulista “Júlio de Mesquita Filho" (Unesp), Campus Araçatuba, Rua Clóvis Pestana 793,Jardim Dona Amélia, Araçatuba,SP16050-680. *Corresponding author: iveraldo.dutra@unesp.br
} 
biofilm with the deposition of iron, and it indicates that the presence of iron and magnesium in these formations may be involved in the metabolism of some microorganisms associated with the etiology of bovine periodontitis.

INDEX TERMS: Supragingival biofilm, bovine, periodontitis, scanning electron microscopy, energy dispersive spectroscopy.

RESUMO.- [Composição química e estrutural do biofilme supragengival pigmentado de bovinos com periodontite.] A periodontite bovina é uma infecção multifatorial associada primariamente à microbiota potencialmente patogênica presente no biofilme bucal. Biofilmes são estruturas organizadas, nas quais os constituintes convivem em simbiose, descritos em outras espécies como um fator predisponente à periodontite. O objetivo do presente estudo foi caracterizar estrutural e quimicamente o biofilme supragengival pigmentado de preto em bovinos, utilizando-se as técnicas de microscopia eletrônica de varredura (MEV) e espectroscopia de dispersão de energia (EDS), respectivamente, correlacionando os elementos identificados à ocorrência de periodontite e pigmentação. Foram avaliados 11 dentes primeiro-molares; cinco amostras sem pigmentação visível e seis amostras com biofilme pigmentado de preto, que foram submetidas inicialmente à MEV; posteriormente foram selecionadas três áreas aleatórias de cada dente para realização da EDS. A estrutura do biofilme pigmentado revelou formações irregulares e mais complexas, provavelmente devido ao maior acúmulo de elementos minerais. Os resultados semi-quantitativos da EDS apontaram associações entre a presença de ferro $(\mathrm{p}<0,014)$ e magnésio $(\mathrm{p}<0,001)$ com a ocorrência de periodontite. Carbono, fósforo, cálcio, manganês, sódio e potássio não apresentaram associação com a periodontite. Em relação à pigmentação, carbono $(\mathrm{p}<0,039)$, manganês $(\mathrm{p}<0,007)$ e ferro $(\mathrm{p}<0,015)$ foram os elementos estatisticamente significantes, enquanto fósforo, cálcio e magnésio não apresentaram associação com a pigmentação. 0 teste de correlação de Spearman demonstrou associações entre os elementos cálcio e fósforo, e ferro e silício. A forte associação do ferro presente no biofilme supragengival com a ocorrência de periodontite, sugere a presença de micro-organismos que utilizam este elemento em seu metabolismo e que possivelmente tenham envolvimento com o desenvolvimento da periodontite bovina. Os resultados inéditos do presente trabalho sugerem que os depósitos pigmentados que se formam na coroa dos dentes de bovinos são um biofilme verdadeiro com deposição de ferro, e indicam que a presença de ferro e magnésio nestas formações pode estar envolvida no metabolismo de alguns dos principais micro-organismos associados à etiologia da periodontite bovina.

TERMOS DE INDEXAÇÃO: Composição química, biofilme supragengival, bovinos, periodontite, microscopia eletrônica de varredura, espectroscopia de dispersão de energia.

\section{INTRODUCTION}

Dental biofilms are dynamic and complex structures that are formed in dental enamel through the organized colonization of multiple microbial species of the buccal environment (Kolenbrander et al. 2002). These biofilms can be classified as subgingival, when they are formed in the gingival sulcus or periodontal pocket, or supragingival, when they are formed on the clinical crown of the teeth (Kolenbrander et al. 2010). Besides acting on oral health maintenance, some bacterial species present in biofilms play an important role in the etiology of periodontal diseases in humans (Hojo et al. 2009, Akcali \& Lang 2017), and animals (Elliott et al. 2005, Rober et al. 2008, Gaetti-Jardim Junior et al. 2012, Borsanelli et al. 2016, Agostinho 2017, Campello 2017).

Periodontitis is a multifactorial infection associated with peculiar bacterial complexes, capable of interacting with host tissues and cells resulting in the release of cytokines, chemokines, and inflammatory mediators responsible for causing destruction of periodontal structures (Holt \& Ebersole 2005, Hajishengallis 2015). These microbial groups are amphibiotic, establishing different types of ecological relationships (Marsh et al. 2011), and occupying ecological niches in healthy gingival sulcus and periodontal pockets (Bosshardt 2018). The interaction between these specific microbial groups, especially Gram-negative anaerobic rods, and environmental conditions is still poorly understood, since cattle periodontitis is more prevalent in animals that remain in newly formed areas or have gone through pasture reform process (Dutra et al. 1986, Dutra \& Döbereiner 2001). In calf periodontal lesions, the mean percentage of pigmented black bacteria is considerably higher when compared to that of the same animals after being transferred to indene areas and showing remission of periodontitis clinical symptoms (Dutra et al. 2000). The disease does not occur without common microorganisms constituents of the microbiota, which are mostly found in the oral biofilm of these animals.

Pseudomonas, Burkholderia, and Actinobacteria are the most prevalent taxa in the subgingival microbioma of healthy cattle, whereas Pophyromonas, Prevotella, and Fusobaterium are more frequent in animals with periodontitis (Borsanelli et al. 2018). The diversity of the microbial biofilm increases with periodontitis, but the factors that lead to tissue changes and the possible structural biochemical characteristics of the oral biofilm in animals with different periodontal conditions are not clear.

The process of accumulation and mineralization of the dental biofilm results in calculus formation. In ruminants, this calculus is generally visualized as an accumulation with brown to black pigmentation strongly adhered to the dental surface. In cows, it was described as covering varying extensions of the masticatory teeth. However, at the time, little was known about the role played by dental calculus in the establishment and progression of periodontitis (Ingham 2001). In small ruminants, black pigmented supragingival calculus was described as a common finding and associated with the occurrence of gingival recession (Agostinho 2017, Campello 2017).

In humans, the main components of dental calculus are calcium, magnesium, fluorine, and carbon dioxide (Gron et al. 1967, 
Fialová et al. 2017), which may be associated with environmental compounds, diet, and habits (Fialová et al. 2017). In cattle, the physical properties of dental enamel have been well characterized; the main constituents of the hydroxyapatite crystals, oxygen, calcium, and phosphorus, appear in high concentrations (Nogueira et al. 2014). Nevertheless, studies on the structure and chemical composition of the supragingival biofilm in cattle and their correlation with periodontitis are quite limited.

Understanding the ecology of supragingival biofilm and its relationship with periodontitis is an important step for advancing the knowledge on the etiology, pathogenesis, control, and prophylaxis of this disease in cattle. The aim of this study was therefore to characterize the structure and chemical aspects of the black pigmented supragingival biofilm using scanning electron microscopy (SEM) and energy dispersive spectroscopy (EDS), respectively, and understand its possible relationship with bovine periodontitis.

\section{MATERIALS AND METHODS}

Sample collection. Eleven maxillary first molar teeth from different bovines, five with no visible pigmentation and six with a visually pigmented black biofilm, were collected (Fig.1). These samples were collected from animals with a mean age of 36 months from a slaughterhouse in the region of Araçatuba, São Paulo, Brazil. Data such as sex, place of origin, diet, dental changes, and approximate age of each animal were obtained. Periodontal condition was established after probing the gingival margin of each tooth. Animals with a periodontal pocket deeper than $5 \mathrm{~mm}$ were considered to present periodontitis. For dental extraction, the area between the third premolar and the second molar teeth was isolated and the gingival mucosa of the first molar was removed with a Molt periosteal elevator. The teeth were extracted from the alveolar bone using a simple bisel chisel and a Mead hammer. Sample collection was performed up to 30 minutes after slaughter to preserve the biofilm structure formed on the buccal surface of the upper first molar.

Preparation of the samples. After extraction, each dental root was sectioned; the samples clinical crowns had a maximum width of $12 \mathrm{~mm}$ and a height and length of less than $30 \mathrm{~mm}$. Then, the organic matter debris was removed from each sample. Samples were washed twice with $300 \mu \mathrm{L}$ of physiological solution ( $\mathrm{NaCl} 0.9 \%$ ), and then, the crown biofilm was fixed with $1 \mathrm{ml}$ of $2 \%$ glutaraldehyde for 30 minutes at room temperature. The biofilm was then dehydrated in sequential ethanol baths ( $1 \mathrm{~mL}$ ) at concentrations $50 \%, 70 \%, 90 \%$, and $100 \%$ for 10 minutes at each concentration. After dehydration and drying, the samples were stored in a container with silica for moisture control (modified from Santana et al. 2013).

Structural characterization by scanning electron microscopy (SEM) and mineral composition analysis by energy dispersive spectroscopy (EDS). For the semi-quantitative analysis of mineral composition of bovine biofilm using EDS, the first molars were fixed with a carbon double-face tape, mounted on a colorless acrylic resin stub, and received a carbon cover (Denton Vaccum Desk II). Images of the biofilms with and without pigmentation on the cervical region of the vestibular face of the first molars were captured using SEM JSM-5600 (Jeol, Tokyo, Japan) with magnifications of 100x and 3000x. Using the adjustment of Jeol's parameters (spot-size between 28-32nm and PHA ideal dead time between $20-25 \%$ ) at $3000 x$ magnification, the SEM images were transferred to the EDS micro-analysis (Energy-dispersive X-ray analysis; Vantage, Noran Instruments, Middleton/WI, USA). In the images captured with a magnification of $3000 \mathrm{x}$, three areas of $81 \mu \mathrm{m}^{2}$ each on the cervical surface of the samples were randomly selected for the semi-quantitative analysis; these areas were bombarded with high energy electrons allowing the detection of dispersive X-rays and evaluation of the characteristic absorption profile of each chemical element. Each absorption spectrum was captured for 100 seconds at $15 \mathrm{kV}$ voltage and $32 \mathrm{~mm}$ working distance. Mean and standard deviation of each registered mineral were calculated.

Statistical analysis. The semi-quantitative values of the mineral elements were correlated with the clinical condition (periodontitis or healthy periodontum) and with the presence of pigmentation using the Student's t-test and the Mann-Whitney test. The possible associations between the different composite elements present in the samples were evaluated using the Spearman correlation test. The predicted significance level was $\mathrm{p}<0.05$. Descriptive evaluations were made based on the SEM images.

Research ethics commission. The experiment was approved by the Ethics Committee on Animal Use (CEUA) of the Faculty of Agrarian and Veterinary Sciences-Unesp, Campus Jaboticabal/SP (Process FCAV-Unesp No. 013966/17).

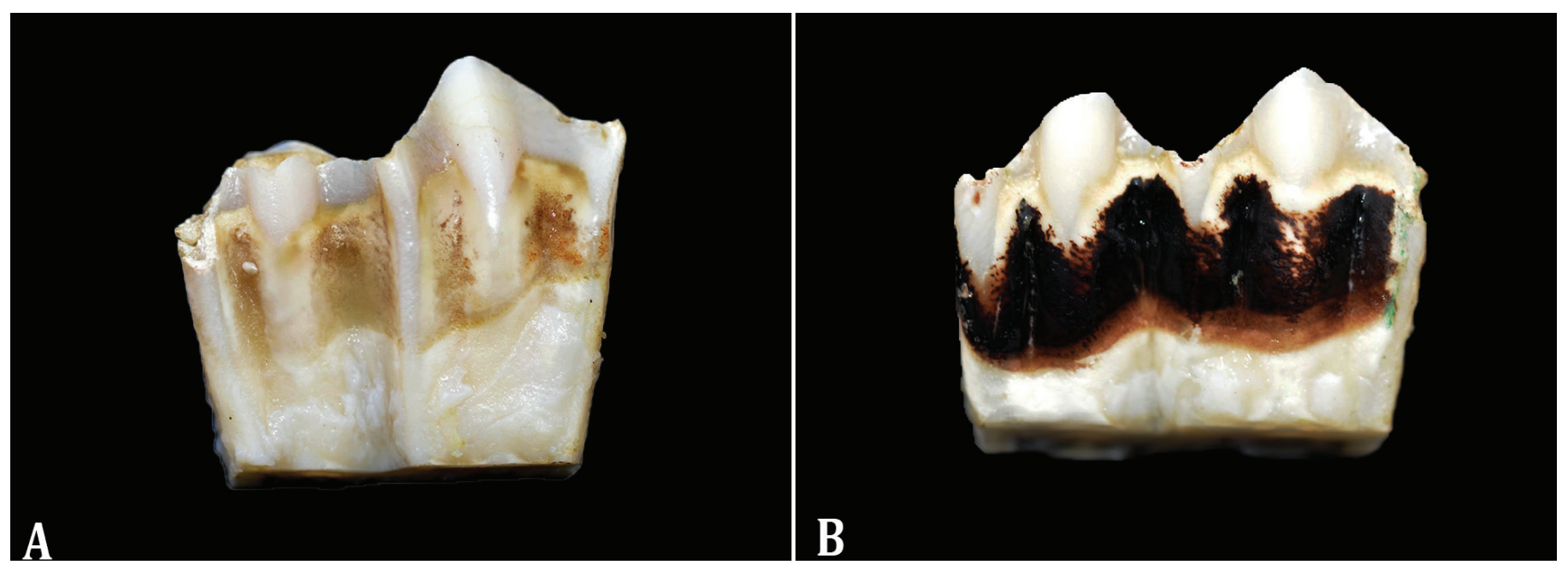

Fig.1. (A) Bovine upper first-molar vestibular face without visible pigmentation. (B) Bovine upper first-molar vestibular face with dark pigmentation. 


\section{RESULTS}

\section{Scanning electron microscopy}

Of the 11 dental arches evaluated, 4 had periodontal pockets at one or more sites. The SEM images of both groups revealed calculus-like formations covered by a biofilm, evidencing the existence of irregular areas with structures that resemble the deposition of oxides and hydroxides, such as calcium hydroxide, and other elements. When the images of the calculus and biofilm without pigmentation were compared with the black pigmented structures, it was observed that these pigmented structures had greater structural complexity, with a more irregular surface and greater abundance of the deposits (Fig.2 and 3). Irregular, coccoid, and bacillary images surrounded by organic and inorganic matrix, suggestive of microbial content, could also be observed.

\section{Energy dispersion spectroscopy}

The Student's t-test showed that iron $(\mathrm{p}<0.014)$ and magnesium $(\mathrm{p}<0.001)$ were associated with the occurrence of periodontitis in the arches of the evaluated animals (Table 1). These results were confirmed by the Mann-Whitney test $(p<0.025$ and $p<0.001$, respectively). Likewise, the carbon content inside the pigmented calculus and biofilm was higher than that observed in non-pigmented samples ( $\mathrm{t}$-Test, $\mathrm{p}<0.039$ ). Other elements such as manganese (Mann-Whitney test, $\mathrm{p}<0.007)$ and iron (Mann-Whitney test, $\mathrm{p}<0.015)$ were also associated with the presence of pigmented biofilm (Table 2). The Spearman's correlation test showed that calcium content increased with increased phosphorus levels, and iron content increased with increased silicon levels, irrespective of the presence of pigmentation in the calculus and dental biofilm or periodontal condition (Table 3).
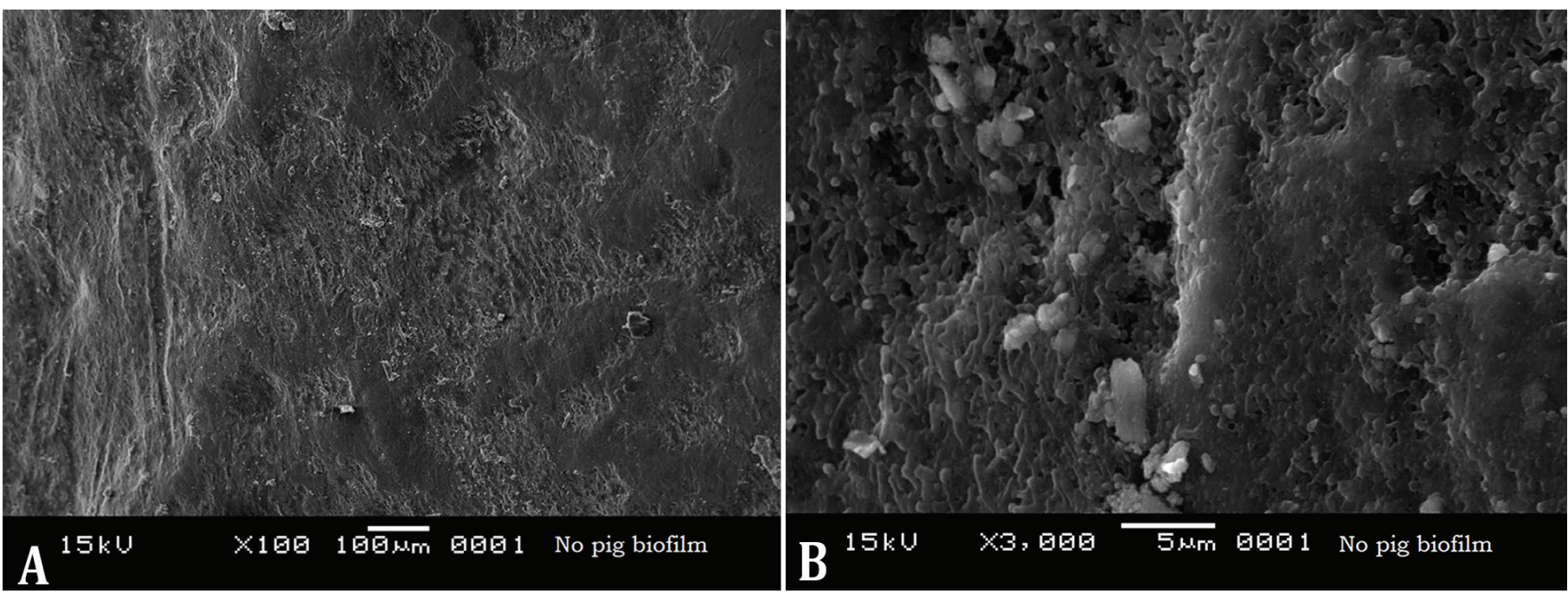

Fig.2. (A) Ultrastructure of the non-pigmented supragingival biofilm of bovine. Magnification = 100x. (B) Surface structure of the biofilm with irregular areas similar to mineral deposition (calcium hydroxides and other elements). Magnification $=3000 \mathrm{x}$.
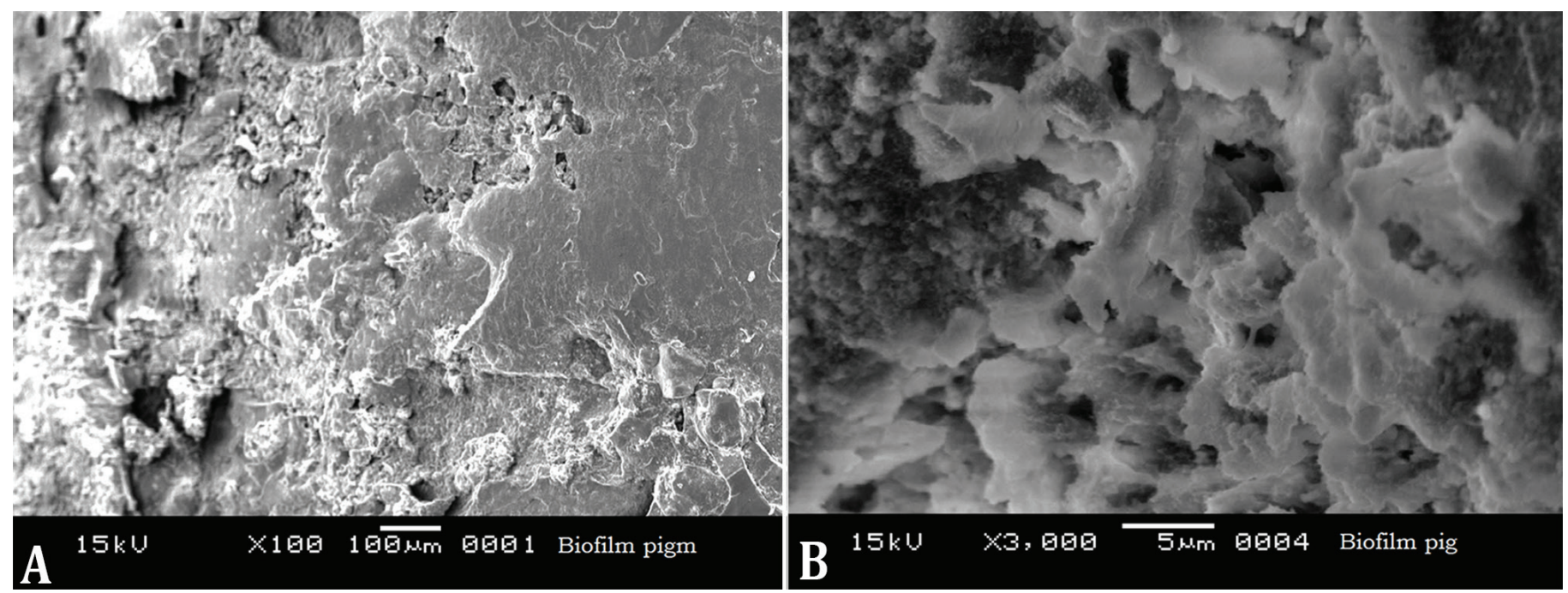

Fig.3. (A) Ultrastructure of pigmented supragingival biofilm of bovine. Magnification = 100x. (B) Surface structure of the pigmented biofilm with irregular areas, high mineral abundance (hydroxides of calcium and other elements), and high structural complexity. Magnification $=3000 \mathrm{x}$. 
Table 1. Significance level of the main chemical elements identified by the energy dispersion spectroscopy technique in the supragingival biofilm of bovines with periodontitis, calculated using the Student's t-test

\begin{tabular}{cccc}
\hline \multirow{2}{*}{ Element } & \multicolumn{2}{c}{ Mean and stardard deviation } & \multirow{2}{*}{ Level of significance } \\
\cline { 2 - 3 } & Animals with periodontitis & Animals periodontally healthy & 0.643 \\
C & $37.0 \pm 13.92$ & $34.02 \pm 14.36$ & 0.438 \\
P & $18.14 \pm 3.87$ & $19.59 \pm 5.61$ & 0.057 \\
Mn & $35.55 \pm 15.29$ & $47.25 \pm 16.88$ & 0.517 \\
Na & $1.67 \pm 0.87$ & $6.38 \pm 17.17$ & 0.490 \\
Fe* & $1.12 \pm 0.27$ & $3.79 \pm 5.06$ & 0.014 \\
Mg* & $28.7 \pm 24.22$ & $6.64 \pm 9.09$ & 0 \\
K & $3.78 \pm 1.28$ & $0.75 \pm 0.46$ & 0.148
\end{tabular}

* Statistically significant elements.

Table 2. Significance level of the main chemical elements identified by the energy dispersion spectroscopy technique in bovine teeth with black pigmented supragingival biofilm, calculated using the Mann-Whitney test

\begin{tabular}{cccc}
\hline \multirow{2}{*}{ Element } & \multicolumn{2}{c}{ Mean } & Level of significance \\
\cline { 2 - 3 } & Non-pigmented teeth & Pigmented teeth & 0.039 \\
C $^{*}$ & 122.00 & 88.00 & 0.895 \\
$\mathrm{P}$ & 244.00 & 284.00 & 0.129 \\
$\mathrm{Ca}$ & 297.00 & 264.00 & 0.007 \\
$\mathrm{Mn} *$ & 67.00 & 123.00 & 0.015 \\
$\mathrm{Fe}^{*}$ & 8.00 & 163.00 & 0.194 \\
$\mathrm{Mg}$ & 33.00 & 87.00 & 0
\end{tabular}

* Statistically significant elements.

Table 3. Major chemical elements detected by the energy dispersion spectroscopy technique in the bovine supragingival biofilm and their correlations with each other, calculated by the Spearman correlation test

\begin{tabular}{|c|c|c|c|c|c|c|c|c|c|c|}
\hline Elements & $\mathrm{C}$ & $\mathrm{P}$ & $\mathrm{Ca}$ & $\mathrm{Mn}$ & $\mathrm{Na}$ & $\mathrm{Fe}$ & $\mathrm{Mg}$ & $\mathrm{K}$ & $\mathrm{Si}$ & $\mathrm{Tl}$ \\
\hline $\mathrm{C}$ & 1.00 & -0.63 & -0.63 & 0.13 & 0.31 & -0.64 & 0.83 & -0.37 & -0.65 & 0.46 \\
\hline $\mathrm{P}$ & -0.63 & 1.00 & 1.00 & -0.85 & -0.93 & -0.19 & -0.96 & -0.48 & -0.18 & -0.98 \\
\hline $\mathrm{Ca}$ & -0.63 & 1.00 & 1.00 & -0.85 & -0.93 & -0.20 & -0.96 & -0.49 & -0.18 & -0.98 \\
\hline $\mathrm{Mn}$ & 0.13 & -0.85 & -0.85 & 1.00 & 0.98 & 0.68 & 0.66 & 0.87 & 0.67 & 0.94 \\
\hline $\mathrm{Na}$ & 0.31 & -0.93 & -0.93 & 0.98 & 1.00 & 0.53 & 0.79 & 0.77 & 0.52 & 0.99 \\
\hline $\mathrm{Fe}$ & -0.64 & -0.20 & -0.20 & 0.68 & 0.53 & 1.00 & -0.10 & 0.95 & 1.00 & 0.39 \\
\hline $\mathrm{Mg}$ & 0.83 & -0.96 & -0.96 & 0.66 & 0.79 & 0.10 & 1.00 & 0.21 & -0.11 & 0.88 \\
\hline $\mathrm{K}$ & 0.37 & -0.48 & -0.49 & 0.87 & 0.77 & 0.95 & 0.21 & 1.00 & 0.95 & 0.65 \\
\hline $\mathrm{Si}$ & 0.65 & 0.18 & -0.18 & 0.67 & 0.52 & 1.00 & -0.11 & 0.95 & 1.00 & 0.38 \\
\hline $\mathrm{Tl}$ & 0.46 & -0.98 & -0.98 & 0.94 & 0.99 & 0.39 & 0.88 & 0.65 & 0.38 & 1.00 \\
\hline
\end{tabular}

Values in bold: maximum correlation $=1.00$.

\section{DISCUSSION}

The development of the microbial biofilm is a relevant step in the implantation and evolution of periodontitis in ruminants (Borsanelli et al. 2015a, 2015b, 2017, Agostinho 2017, Campello 2017), a cause that limits productivity and animal welfare (Borsanelli et al. 2016). Although the current advances in the microbiological studies of periodontal diseases are significant, little is known about the nature, structure, and composition of the biofilm and calcified formations associated with it, such as the dental calculus in cattle.

Biofilm formation and development process, as described in human patients (Marsh et al. 2011, Bosshardt 2018, Marsh
\& Zaura 2017), depends on the nonspecific interaction between the bacterial cell surface and the components of the acquired film and the dental surface (Marsh et al. 2011), creating conditions for more intense and specific interactions between microbial adhesins and their receptors in the host (Socransky \& Haffajee 2002, Marsh et al. 2011). In addition to these microbial and host cellular components, the composition of the liquid environment is also relevant (Malamud 1985), and oral conditions imply salivary composition, which results from the diet (Kolenbrander et al. 2010, Fialová et al. 2017). It is particularly relevant to highlight that in ruminant animals the chemical and microbial content of the rumen interacts 
with the oral counterparts (Myer et al. 2015). Among the microbial adhesins, the role played by fimbriae and other appendicular structures deserves attention (Marsh et al. 2011), especially among the main periodontal pathogens, such as the genus Porphyromonas (Socransky \& Haffajee 2005, Nagano et al. 2018).

The absorption of calcium and phosphate from the saliva and the consequent mineralization of the biofilm result in the formation of the supragingival calculus, which manifests itself in layers that are differentiated by mineral content (Friskopp \& Isacsson 1984). Structurally, dental calculus is covered by a layer of metabolically active microorganisms that accumulate in both periodontally healthy and diseased teeth (Friskopp \& Hammarström 1980). In humans, the association of dental calculus with periodontal diseases is well established (Akcali \& Lang 2017).

Calcium phosphate can be considered one of the most important components of dental tissue formation. Irregular crystallization of these inorganic constituent in biological tissues results in pathological conditions such as dental calculus formation (Dorozhkin \& Epple 2002). In addition to the salivary flow rate, salivary supersaturation with calcium phosphate salts is a factor that favors calculus formation (Jin \& Yip 2002). In the present study, calcium and phosphorus were correlated regardless of the animal's clinical condition or presence of pigmentation, as observed between iron and silicon (Table 3).

In humans, silicon is present in the saliva, biofilm, and dental calculus. A large part of this element is found in the form of silica in food (Jin \& Yip 2002), and, at concentrations of 0-2mg/ $\mathrm{mL}$, it acts as a stimulant factor for the precipitation of calcium phosphate (Damen \& Ten Cate 1989). When incorporated into the diet, silica may increase the rate of dental calculus formation (Gaare et al. 1989), probably because of the ability of calcium to bind to silicic acids and silica (Jin \& Yip 2002). The food factor was not evaluated in the present study, and the findings associated with this element need to be further investigated.

SEM images of the supragingival calculus in human patients are characterized by the presence of heterogeneous content covered by filamentous microorganisms (Friskopp \& Hammarström 1980). In bovines, the images of the calculus covered by supragingival biofilm (pigmented and non-pigmented) indicated the presence of structural formations with irregular areas, possibly resulting from mineral deposits similar to those described by Salles et al. (2012). These irregular deposits appear in greater abundance in pigmented samples. Cocoid and bacillary morphology structures were also observed, which suggests the presence of microbial content covering the supragingival calculus.

During its initial development, biofilm increases in thickness and microbial co-aggregation networks and physiological interconnections are established between the bacterial components of the biofilm, independently of the host species and even in in vitro studies (Sanguansermsri et al. 2017, Neilands et al. 2019). Favorable conditions are therefore created for the establishment of complex microbial communities (Lang et al. 2010). According to Jin \& Yip (2002), the mineralization of this biofilm is a natural consequence of the physical and chemical aspects present in the mouth, in which saliva and diet provide mineral elements such as calcium and phosphorus, which are a large part of the deposited mineral content (Table 2).

The semi-quantitative analysis using EDS indicated a strong correlation of the presence of iron and magnesium with the occurrence of periodontitis. Iron is an essential element for the growth and metabolic function of most living organisms, acting at different stages of cellular catabolism and anabolism, such as redox reactions, oxidative radical transport, DNA synthesis, and free radical scavenging mechanisms (Lewis 2010). However, the focus of the present study was the role of iron as an element that controls the expression of numerous microbial virulence factors, potentiating damage to host tissues (Schaible \& Kaufmann 2004). In this context, some of the major oral microorganisms, such as the genera Porphyromonas and Prevotella, accumulate iron derived from gingival and periodontal bleeding as little water-soluble compounds with dark pigmentation (Smalley et al. 2003) as was observed in the bovine microbial biofilms, especially in animals with periodontitis. This relationship between iron, calculus pigmentation and oral biofilm, and presence of bone loss in cattle was also observed in the present study (Table 1 and 2).

With the establishment of the inflammatory framework in the insertion periodontal tissues, the amount of iron bound to blood proteins present in the gingival fluid increases significantly, so bleeding related to periodontal destruction provides hemin resulting from the hemolysis process and may modify the microbiota interaction (Lewis 2010) to act as a protective molecule in oxidative stress (Smalley et al. 1998).

Since $76 \%$ of iron available to mammals is stored as heme groups in oxygen-carrying cells such as hemoglobin and myoglobin, the major microorganisms associated with periodontal infections eventually associate the expression of proteases and peptidases with the presence of iron (Lewis 2010, Byrne et al. 2013), as well as surface receptors and transport proteins (Shoji et al. 2010). This constitutes a strategy to obtain iron besides acquiring the amino acids that will be used in its fermentative metabolism, which ends up releasing several toxic compounds (Olczak et al. 2005); capable of inhibiting cell proliferation and tissue repair, besides presenting direct toxic action on host cells (Lewis 2010).

As the oral biofilm of different host species presents bacteria genera capable of intense proteolytic metabolism and iron deposition, besides being involved with the periodontal destruction (Lewis 2010, Byrne et al. 2013), it can be assumed that these microorganisms are involved in the formation of these deposits and in the observed periodontal destruction.

Previous studies by the same research group have shown that bacteria of the genera Porphyromonas and Prevotella, such as Porphyromonas gingivalis, Porphyromonas endodontalis, Prevotella melaninogenica, and Prevotella buccae, which require hemin supplementation for in vitro growth, are among the main microorganisms detected in periodontal pockets of cattle and other ruminants (Dutra et al. 1986, Borsanelli et al. 2015b, 2017, 2018). This association between the genera Porphyromonas and Prevotella and periodontitis in cattle has been discussed, and Borsanelli et al. (2015b) showed that the presence of P. endodontalis, P. melaninogenica, and Prevotella intermedia was much higher in animals with periodontal bone loss than in periodontally healthy animals. 
In addition to iron, the semi-quantitative analysis using EDS revealed an association between magnesium and periodontitis, already reported as one of the elements in human dental calculus (Fialová et al. 2017). Magnesium is an essential element for bacterial metabolism, which directly interferes with cell multiplication rates of a wide variety of species (Gadd 1992). Magnesium deficiency can lead to degradation of the ribonucleoprotein complex and it is associated with loss of cell viability (Walker 1994). However, the metabolic activity of magnesium in the dental biofilm and its relation to periodontitis in cattle is still unknown.

The semi-quantitative analysis also showed that carbon, manganese, and iron were significantly correlated with tooth pigmentation. Most of the pathogenic bacteria are heterotrophic and use carbon, which is present in a large variety of substrates, as a source of energy (Muñoz-Elías \& McKinney 2006). It is possible that the iron deposits present in the pigmented calculus and biofilm samples are linked to organic compounds, rich in carbon, which would justify the association of these elements, as noted in the present study.

Manganese is an important element in bacterial metabolism that, as well as iron, also acts to protect oxidative stress. In addition, this element is involved in other functions during infection, for example, in regulating the expression of genes associated with virulence. In its non-enzymatic form, manganese is important to maintain bacterial viability in aerobic environments, among other activities (Zaharik \& Finlay 2004, Lewis 2010). Like magnesium, the function of manganese in the dental biofilm of cattle and other species is little known.

Black pigmented supragingival biofilm has been associated with a higher degree of gingival recession in dairy goats. In the same study, the sites with major lesions were in the masticatory teeth (Campello 2017). Agostinho (2017) reported similar findings between presence of supragingival biofilm and gingival recession in sheep and also noted that older animals presented larger amounts of these microbial deposits. Although these deposits may also occur in young animals and not always linearly, these associations may indicate that the accumulation of supragingival biofilm acts as an important risk factor for the development and progression of periodontitis in small ruminants.

In the subgingival biofilm of bovines with periodontitis, it was possible to demonstrate similarities in the identification of some periodontopathogens already recognized in human periodontitis (Borsanelli et al. 2015a, 2015b, Borsanelli 2017). Little is known about the microbiological composition of the supragingival biofilm of cattle, but the associations found in the present study may indicate an important role of the microbiota residing in these formations and of their chemical metabolites in the triggering and pathogenesis of this disease in cattle.

\section{CONCLUSIONS}

The structures formed on bovine dental surfaces corroborate the existence of a biofilm of microbial origin, which mineralizes and is structured into a supragingival calculus.

The dark pigmentation on the dental surface of cattle probably results from the deposition of iron in the supragingival biofilm of these animals, since some oral microorganisms have their metabolism deeply linked to the metabolism of this element.
The association between the presence of iron and magnesium in the supragingival biofilm and the occurrence of periodontitis in cattle may indicate an important role of the supragingival microbiota and its metabolites in the etiology of bovine periodontitis.

Acknowledgments.- The present work was carried out with the support of the "Coordenação de Aperfeiçoamento de Pessoal de Nível Superior" (CAPES), Brazil, Financing Code 001; the agricultural technician Adão Ângelo Custódio, from the Department of Support, Production and Animal Health, Faculty of Veterinary Medicine, Unesp-Araçatuba, for the technical services provided; Professor Yuri Tani Utsunomya, Department of Support, Production and Animal Health, Faculty of Veterinary Medicine, Unesp-Araçatuba, for his assistance in the statistical analysis; supervisor Adriano Luis Martins, Center of Microscopy and Images, Fop-Unicamp, for the technical services provided.

Conflict of interest statement.- The authors have no competing interests.

\section{REFERENCES}

Agostinho S.D. 2017. Periodontite e desgaste dentário em ovinos. Doctor of Science in Veterinary Medicine, Faculdade de Ciências Agrárias e Veterinárias, Universidade Estadual Paulista, Jaboticabal, SP. 78p.

Akcali A. \& Lang N.P. 2017. Dental calculus: the calcified biofilm and its role in disease development. Periodontol. 2000 76(1):109-115.<http://dx.doi. org/10.1111/prd.12151><PMid:29194797>

Borsanelli A.C. 2017. Genotipagem de bactérias anaeróbias associadas às lesões da periodontite bovina. Doctor of Science in Veterinary Medicine, Faculdade de Ciências Agrárias e Veterinárias, Universidade Estadual Paulista, Jaboticabal, SP. 116p.

Borsanelli A.C., Gaetti-Jardim Junior E., Döbereiner J. \& Dutra I.S. 2015a. Treponema denticola in microflora of bovine periodontitis. Pesq. Vet. Bras. 35(3):237-240. <http://dx.doi.org/10.1590/S0100-736X2015000300005>

Borsanelli A.C., Gaetti-Jardim Júnior E., Schweitzer C.M., Döbereiner J. \& Dutra I.S. 2015b. Presence of Porphyromonas and Prevotella species in the oral microflora of cattle with periodontitis. Pesq. Vet. Bras. 35(10):829-834. <http://dx.doi.org/10.1590/S0100-736X2015001000002>

Borsanelli A.C., Viora L., Lappin D.F., Bennett D., King G., Dutra I.S. \& Riggio M.P. 2016. Periodontal lesions in slaughtered cattle in the west of Scotland. Vet. Rec. 179(25):652. <http://dx.doi.org/10.1136/vr.103931><PMid:27780900>

Borsanelli A.C., Gaetti-Jardim Junior E., Schweitzer C.M., Viora L., Busin V., Riggio M.P. \& Dutra I.S. 2017. Black-pigmented anaerobic bacteria associated with ovine periodontitis. Vet. Microbiol. 203:271-274. <http://dx.doi. org/10.1016/j.vetmic.2017.03.032> <PMid:28619155>

Borsanelli A.C., Lappin D.F., Viora L., Bennett D., Dutra I.S., Brandt B.W. \& Riggio M.P. 2018. Microbiomes associated with bovine periodontitis and oral health. Vet. Microbiol. 218:1-6. <http://dx.doi.org/10.1016/j. vetmic.2018.03.016><PMid:29685214>

Bosshardt D.D. 2018. The periodontal pocket: pathogenesis, histophatology and consequences. Periodontol. 2000 76(1):43-50. <http://dx.doi. org/10.1111/prd.12153><PMid:29194796>

Byrne D.P., Potempa J., Olczak T. \& Smalley J.M. 2013. Evidence of mutualism between two periodontal pathogens: co-operative haem acquisition by the HmuY haemophore of Porphyromonas gingivalis and the cysteine protease interpain A (InpA) of Prevotella intermedia. Mol. Oral Microbiol. 28(3):219229. <http://dx.doi.org/10.1111/omi.12018><PMid:23336115>

Campello P.L. 2017. Periodontite e desgaste dentário em cabras leiteiras. Doctor of Science in Veterinary Medicine, Faculdade de Ciências Agrárias e Veterinárias, Universidade Estadual Paulista, Jaboticabal, SP. 111p.

Damen J.J. \& Ten Cate J.M. 1989. The effect of silic acid on calcium phosphate precipitation. J. Dent. Res. 68(9):1355-1359. <http://dx.doi.org/10.1177 /00220345890680091301> <PMid:2550533> 
Dorozhkin S.V. \& Epple M. 2002. Biological and medical significance of calcium phosphates. Rev. 41(17):3130-3146. <http://dx.doi.org/10.1002/15213773(20020902)41:17<3130::AID-ANIE3130>3.0.C0;2-1><PMid:12207375>

Dutra I.S. \& Döbereiner J. 2001. Cara inchada dos bovinos, p.397-401. In: Riet-Correa F., Schild A.L., Lemos R.A.A. \& Borges J.R.J. (Eds), Doenças de Ruminantes de Equídeos. $2^{\text {a }}$ ed. Varela, São Paulo.

Dutra I.S., Kanoe M. \& Blobel H. 1986. Atividades enzimáticas e endotóxicas de bactérias isoladas de lesões peridentárias da "cara inchada" dos bovinos. Pesq. Vet. Bras. 6(2):59-69.

Dutra I.S., Botteon R.C.M. \& Döbereiner J. 2000. Modificação da microbiota associada às lesões peridentárias da "cara inchada" em bezerros transferidos para área indene. Pesq. Vet. Bras. 20(2):71-74. <http://dx.doi.org/10.1590/ S0100-736X2000000200003>

Elliott D.R., Wilson M., Buckley C.M. \& Spratt D.A. 2005. Cultivable oral microbiota of domestics dogs. J. Clin. Microbiol. 43(11):5470-5476.<http:// dx.doi.org/10.1128/JCM.43.11.5470-5476.2005><PMid:16272472>

Fialová D., Skoupý R., Drozdová E., Paták A., Piños J., Sín L., Beñus R. \& Klíma B. 2017. The application of scanning electron microscopy with energydispersive X-ray spectroscopy (SEM-EDX) in ancient dental calculus for the reconstruction of human habits. Microsc. Microanal. 23(6):1207-1213. <http://dx.doi.org/10.1017/S1431927617012661><PMid:29151368>

Friskopp J. \& Hammarström L. 1980. A comparative scanning electron microscopy study of supragingival and subgingival calculus. J. Periodontol. 51(10):553-562. <http://dx.doi.org/10.1902/jop.1980.51.10.553> <PMid:6934286>

Friskopp J. \& Isacsson G. 1984. A quantitative microradiographic study of mineral content of supragingival and subgingival dental calculus. Scand. J. Dent. Res. 92(1):417-423. <http://dx.doi.org/10.1111/j.1600-0722.1984. tb00855.x><PMid:6585908>

Gaare D., Rolla G. \& Van Der Ouderaa F. 1989. Comparison of the rate of formation of supragingival calculus in an Asian and a European population, p.115-122. In: Ten Cate J.M. (Ed.), Recent advances in the study of dental calculus. Oxford University Press, Oxford.

Gadd G.M. 1992. Metals and microorganisms: a problem of definition. FEMS Microbiol. Lett. 100(1/3):197-204.<http://dx.doi.org/10.1111/j.1574-6968.1992. tb05703.x $><$ PMid:1478456>

Gaetti-Jardim Junior E., Monti L.M., Ciesielski F.I.N., Gaetti-Jardim E.C., Okamoto A.C., Schweitzer C.M. \& Avila-Campos M.J. 2012. Subgingival microbiota from Cebus paella (Capuchin monkey) with diferent periodontal conditions. Anaerobe 18(3):263-269. <http://dx.doi.org/10.1016/j. anaerobe.2012.02.002> <PMid:22710412>

Gron P., Van Campen G.J. \& Lindstrom I. 1967. Human dental calculus. Inorganic chemical and crystallographic composition. Arch. Oral. Biol. 12(7):829-837. <PMid:5231454>

Hajishengallis G. 2015. Periodontitis: from microbial immune subversion to systemic inflammation. Nature 15(1):30-44. <PMid:25534621>

Hojo K., Nagaoka S., Ohshima T. \& Maeda N. 2009. Bacterial interactions in dental biofilm development. Crit. Rev. Oral Biol. Med. 88(11):982-990. <PMid:19828884>

Holt S.C. \& Ebersole J.L. 2005. Porphyromonas gingivalis, Treponema denticola and Tannerella forsythia: the 'red complex', a prototype polybacterial pathogenic consortium in periodontitis. Periodontol. 2000 38(1):72-122. <http://dx.doi.org/10.1111/j.1600-0757.2005.00113.x><PMid:15853938>

Ingham B. 2001. Abbatoir survey of dental defects in cull cows. Vet. Rec. 148(24):739-742. <http://dx.doi.org/10.1136/vr.148.24.739> <PMid:11442231>

Jin Y. \& Yip H.K. 2002. Supragingival calculus: formation and control. Crit. Rev. Oral Biol. Med.13(5):426-441.<http://dx.doi.org/10.1177/154411130201300506> $<$ PMid:12393761>

Kolenbrander P.E., Palmer Junior R.J., Periasamy S. \& Jakubovics N.S. 2010. Oral multispecies biofilm development and the key role of cell-cell distance. Nat. Rev., Microbiol. 8(7):471-480. <http://dx.doi.org/10.1038/ nrmicro2381><PMid:20514044>

Kolenbrander P.E., Andersen R.N., Blehert D.S., Egland P.G., Foster J.S. \& Palmer Junior R.J. 2002. Communication among oral bacteria. Microbiol. Mol. Biol. Rev. 66(3):486-505. <http://dx.doi.org/10.1128/MMBR.66.3.486505.2002><PMid:12209001>

Lang N.P., Mombelli A. \& Attström R. 2010. Biofilmes e cálculos orais, p.173196. In: Lindhe J., Lang N.P \& Karring T. (Eds), Tratado de Periodontia Clínica e Implantologia Oral. 5aㅡ ed. Guanabara Koogan, Rio de Janeiro.

Lewis J.P. 2010. Metal uptake in host-pathogen interactions: role of iron in Porphyromonas gingivalis interactions with host organisms. Periodontol. 2000 52(1):94-116. <http://dx.doi.org/10.1111/j.1600-0757.2009.00329. $\mathrm{x}><$ PMid:20017798>

Malamud D. 1985. Influence salivary proteins on the fate of oral bacteria, p.7-13. In: Mergenhagen S.E. \& Rosan B. (Eds), Molecular Basis of Oral Microbial Adhesion. ASM, Washington.

Marsh P.D. \& Zaura E. 2017. Dental biofilm: ecological interactions in health and disease. J. Clin. Periodontol. 44(Suppl.18):12-22. <http://dx.doi. org/10.1111/jcpe.12679><PMid:28266111>

Marsh P.D., Annete M. \& Devine D.A. 2011. Dental plaque biofilms: communities, conflict and control. Peridontol. 2000 55(1):16-35. <http://dx.doi. org/10.1111/j.1600-0757.2009.00339.x>

Muñoz-Elías E.J.\& McKinney J.D. 2006. Carbon metabolism of intracellular bacteria. Cell. Microbiol. 8(1):10-22.<http://dx.doi.org/10.1111/j.1462-5822.2005.00648. $\mathrm{x}><$ PMid:16367862>

Myer P.R., Smith T.P.L., Wells J.E., Kuehn L.A. \& Freetly H.C. 2015. Rumen microbiome from steers differing in feed efficiency. Plos One 10(6):e0129174. <http://dx.doi.org/10.1371/journal.pone.0129174><PMid:26030887>

Nagano K., Hasegawa Y., Iijima Y., Kikuchi T. \& Mitani A. 2018. Distribution of Porphyromonas gingivalis fimA and $\mathrm{mfal}$ fimbrial genotypes in subgingival plaques. Peer J. 6:e5581. <http://dx.doi.org/10.7717/peerj.5581> <PMid:30186705>

Neilands J., Davies J.R., Bikker F.J. \& Svensäter G. 2019. Parvimonas micra stimulates expression of gingipains from Porphymonas gingivalis in multispecies communities. Anaerobe 55:54-60. <http://dx.doi.org/10.1016/j. anaerobe.2018.10.007><PMid:30359695>

Nogueira B.C.L., Fernandes P.M., Paiva A.C.J., Fagundes N.C.F., Teixeira F.B. \& Lima R.R. 2014. Avaliação comparativa da ultraestrutura e propriedades físicas do esmalte bovinos, bubalino e humano. Pesq. Vet. Bras. 34(5):485490. <http://dx.doi.org/10.1590/S0100-736X2014000500017>

Olczak T., Simpson W., Liu X. \& Genco C.A. 2005. Iron and heme utilization in Porphyromonas gingivalis. Microbiol. Rev. 29(1):119-144. <PMid:15652979>

Rober M., Quirynen M., Haffajee A.D., Schepers E. \& Teughels W. 2008. Intraoral microbial profiles of beagle dogs assessed by checkerboard DNA-DNA hybridization using human probes. Vet. Microbiol. 127(1/2):79-88. <http:// dx.doi.org/10.1016/j.vetmic.2007.08.007> <PMid:17897795>

Salles L.P., Gomes-Cornélio A.L., Guimarães F.C., Herrera B.S., Bao S.N., RossaJúnior C., Guerreiro-Tanomaru J.M. \& Tanomaru-Filho M. 2012. Mineral Trioxide Aggregate-based endodontic sealer stimulates hydroxyapatite nucleation in human osteoblast-like cell culture. Basic Res. Technol. 38(7):971976. <http://dx.doi.org/10.1016/j.joen.2012.02.018><PMid:22703663>

Sanguansermsri P., Nobbs A.H., Jenkinson H.F. \& Surarit R. 2017. Interespecies dynamics among bacteria associated with canine periodontal disease. Mol. Oral. Microbiol. 33(1):59-67. <http://dx.doi.org/10.1111/omi.12199> <PMid:28960881>

Santana L.N.S., Barbosa L.V.M., Teixeira F.B., Costa A.M.P., Fernandes L.M.P. \& Lima R.R. 2013. Morphology of the dentin structure of sloths brady-pus tridactylus: a light and scanningelectron microscopy investigation. Anat. Histol. Embryol. 46(6):410-414.<http://dx.doi.org/10.1111/ahe.12029> <PMid:23410180>

Schaible U.E. \& Kaufmann S.H.E. 2004. Iron and microbial infection. Nat. Rev., Microbiol. 2(12):946-953. <http://dx.doi.org/10.1038/nrmicro1046> $<$ PMid:15550940> 
Shoji M., Shibata Y., Shiroza T., Yukitake H., Peng B., Chen Y.Y., Sato K., Naito M., Abiko Y., Reynolds E.C. \& Nakayama K. 2010. Characterization on hemin-binding protein 35 (HBP35) in Porphyromonas gingivalis: its cellular distribution, thioredoxin activity and role in heme utilization. BMC Microbiol. 10(152):1471-2180. <http://dx.doi.org/10.1186/14712180-10-152><PMid:20500879>

Smalley J.W., Silver J., Marsh P.J. \& Birss A.J. 1998. The periodontopathogen Porphyromonas gingivalis binds iron protoporphyrin IX in the mu-oxo dimeric for: an oxidative buffer and possible pathogenic mechanism. Biochem. J. 331(Pt 3):681-685. <http://dx.doi.org/10.1042/bj3310681> <PMid:9560292>

Smalley J.W., Silver J., Birss A.J., Withnall R. \& Titler P.J. 2003. The haem pigment of the oral anaerobes Prevotella nigrescens and Prevotella intermedia is composed of iron (III) protoporphyrin IX in the monomeric form. Microbiol. 149(Pt 7):1711-1718. <http://dx.doi.org/10.1099/ mic.0.26258-0 > <PMid:12855722>

Socransky S.S. \& Haffajee A.D. 2002. Dental biofilms: difficult therapeutic targets. Periodontol. 2000 28(1):12-55. <http://dx.doi. org/10.1034/j.1600-0757.2002.280102.x ><PMid:12013340>

Socransky S.S. \& Haffajee A.D. 2005. Relationship of bacteria to the etiology of periodontal disease. J. Dent. Res. 49(2):203-222. <http://dx.doi.org/1 0.1177/00220345700490020401><PMid:4313844>

Walker G.M. 1994. The roles of magnesium in biotechnology. Crit. Rev. Biotechnol. 14(4):311-354. <http://dx.doi.org/10.3109/07388559409063643> $<$ PMid:7889576>

Zaharik M.L. \& Finlay B.B. 2004. Mn+2 and bacterial pathogenesis. Front. Biosc. 9(1/3):1035-1042.<http://dx.doi.org/10.2741/1317><PMid:14977526> 